\title{
ПРОСВІТНИЦЬКА РОБОТА КУРАТОРА ГРУПИ ЩОДО ФОРМУВАННЯ СТАТЕВОЇ КУЛЬТУРИ ПІДЛІТКІВ
}

\author{
Н. В. Попович \\ Міжгірський медичний коледж \\ ДВНЗ «Тернопільський державний медичний університет \\ імені І. Я. Горбачевського МОЗ Украӥни”
}

У статті розглянуто аспекти роботи кураторів академгруп. Підтверджено, що належним чином організована діяльність наставників академгруп виступає важливою умовою цілеспрямованого формування світогляду особистості.

\section{EDUCATIONAL WORK OF GROUP SUPERVISOR IN MEANS OF FORMATION OF GENDER CULTURE OF TEENAGERS}

\author{
N. V. Popovych \\ Mizhhirsky Medical College \\ I. Horbachevsky Ternopil State Medical University
}

The article deals with the aspects of work of group supervisor. It confirmes that properly organized work of group supervisor is an important condition for the purposeful formation of a person's outlook.

Вступ. Серед нагальних проблем сьогодення постає виховання здорового підростаючого покоління у духовному, психічному та фізичному аспектах. Надзвичайно важливу роль у зазначеному контексті відіграє статеве виховання сучасної молоді [1]. Останніми роками ця проблема набуває ще більшої актуальності. Це зумовлюється багатьма чинниками, серед яких: збільшення випадків небажаної вагітності серед дівчат шкільного віку, розповсюдження хвороб, що передаються статевим шляхом, зниження моральності серед осіб підліткового віку, сексуальна розбещеність тощо. Формування статевої культури підлітків - частина культури майбутнього суспільства. На сучасному етапі розвитку суспільства роль соціальних зв'язків у формуванні статевої культури є однією з найактуальніших у соціальній теорії та практиці [1, 2].

Основна частина. Як показує практика, спроби перекласти статеве виховання тільки на сім'ю виявляються невдалими через низьку сексуальну культуру і педагогічну непідготовленість самих батьків. 3 іншого боку, робота освітньо-виховних установ без контакту з сім'ями виявиться малоефективною, оскільки саме в

(c) Н. В. Попович, 2018 родині закладаються і формуються основні етичні та психологічні характеристики дитини [3, 4].

Статеве виховання дітей починають їхні батьки, навіть якщо самі про це не знають чи не хочуть цього. При цьому більшість батьків не забиває дітям голови думками про секс. Вони вже і так про нього думають. Сексуальні переживання й інтерес до сексу цілком природні і нормальні для всіх дітей $[5,6]$. Молоді люди, які виросли в родинах, де прийнято відверто говорити про сексуальність, як правило, поводяться більш відповідально. Відкрита комунікація принаймні дозволяє молодим людям усвідомити власні сексуальні почуття і вчинки та позбутися пов'язаних із ними негативних переживань. Батьки і родина в цілому повинні відігравати важливу роль у становленні сексуальності дитини. Так, для того, щоб у родині виросла здорова людина з високою сексуальною культурою, необхідно, щоб батьки: показували своїм дітям-підліткам, як вони їх цінують, поважають, приймають такими, які вони є, і довіряють їм; демонстрували дітям, що сексуальність $є$ частиною нормального людського життя і не заслуговує несхвалення чи осуду; на власному прикладі демонстрували сексуально здорові сімейні 
стосунки; самі були добре інформованими в питаннях сексу; обговорювали сексуальні теми зі своїми дітьми; намагалися зрозуміти погляди своїх дітей; виявляли активну зацікавленість життям підлітка; регламентували правила, що стосуються побачень і проведення вільного часу, і стежили, щоб діти їх дотримувались; пропонували дітям свою допомогу, якщо потрібно звернутися до лікаря; допомагали підліткам будувати плани на майбутнє $[7,8]$. Також потрібно враховувати той факт, що у традиціях українських сімей неприйнято говорити з підлітками на теми сексу, обговорювати з дітьми питання планування сім'ї, запобігання незапланованій вагітності, наслідків ранніх сексуальних стосунків, профілактики хвороб, які передаються статевим шляхом. Отже, очевидна необхідність взаємодії сім'ї й освітньо-виховних установ як інститутів, що мають найсильніший вплив на формування статевої культури підлітків. На макросоціальному рівні потрібне вироблення єдиної концептуальної основи й узгодження стратегії і тактики роботи з підростаючим поколінням всіх інститутів соціалізації, а також міністерств і відомств, у сфері діяльності яких знаходиться соціальна робота з дітьми та молоддю.

У той же час, багато вчених дотримуються тієї думки, що дітям корисно навчатися також за позасімейними програмами статевого виховання, що не заміщують, а доповнюють домашні уроки. Це зумовлено такими причинами: деякі батьки чи діти, стикаючись у сімейному чи громадському житті з темою чи подією, які мають відношення до сексуальності, настільки бентежаться, що просто не можуть обговорювати цю тематику; деякі батьки чекають, коли діти почнуть ставити їм запитання про сексуальність, але діти про це не запитують, чи батьки не зважають на питання, задані у непрямій формі; деякі батьки просто не мають необхідної інформації (за винятком найпростіших - про те, звідки беруться діти), щоб відповісти на питання своїх дітей; людям, які отримали спеціальну педагогічну підготовку, простіше повідомити дітям інформацію, зрозуміло й об'єктивно, ніж батькам, які занадто емоційно ставляться до своїх дітей; у групі можна створити «безпечну», частково структуровану ситуацію, у якій молодим людям легше висловитися, ніж у сімейній обстановці. Крім того, у них з'являється можливість вчитися мовчки, слухаючи, як інші обмінюються думками.

Сучасна науково обґрунтована програма статевого виховання і сексуальної освіти повинна включати нерозривно пов'язані навчальний (інформаційно- просвітницький плюс інструментальний) і виховний (особистісно-орієнтований) компоненти, що забезпечують формування у молодих людей адекватних етичних норм, ціннісних орієнтацій, знань і навичок, прийнятних на особистісному рівні і реалізовуваних у поведінці. При цьому навчально-виховний процес повинен мати випереджаючий і профілактичний, а не сексуально-стимулюючий характер і орієнтуватися на норму і позитивні аспекти сексуального буття, а не на відхилення як засіб залякування. В ідеологічному плані питання про необхідність такого роду програм із проблем статі та сексуальних стосунків спочатку пов'язане не стільки з полемікою про біологічну або соціальну детермінацію психосексуального розвитку і сексуальної поведінки, скільки з наявністю вибору між репресивним, ліберальним, пасивно-нейтральним і демократичним підходами до статевого виховання.

Найоптимальнішим є демократичний підхід, що припускає, з одного боку, визнання самого факту існування проблеми статі й міжстатевих стосунків і права дитини (підлітка) на відповідну частину свого буття, з іншого, «вбудовування» на суворо науковій основі в об'єкти педагогічної дії таких життєвих цінностей, знань, навичок, норм поведінки, що були б обмежувачами для можливих відхилень у процесі статевої соціалізації дитини. При цьому об'єкту педагогічного впливу надається вся необхідна інформація і в той же час - можливість вибору. У числі основних параметрів, на які спрямована соціально-педагогічна дія, можна виділити такі: психічна стать, статева ідентичність; еталони маскулінності-фемінності; ставлення до протилежної статі; міжгендерна комунікація і взаємодія, у тому числі уміння вести переговори; особистісні характеристики, особливо такі, як відповідальність, толерантність, здатність ухвалювати рішення, вміння контролювати свої бажання й імпульсивну поведінку; матримоніальні цінності і готовність до виконання сімейних ролей - подружніх і батьківських. Сексуальна (статева) освіта має на меті формування таких установок, знань і практичних навичок, що максимально забезпечили 6 високу якість сексуального здоров'я і стали основою нормального психосексуального розвитку і поведінки.

На нашу думку, обов'язковими елементами будьякої програми статевого виховання мають бути такі: повна фактична інформація про біологічні аспекти статі та репродукції; основні дані про контроль за народжуваністю та планування сім'ї; різниця між сексуальною поведінкою (СП) тварини і людини (тварини, 
в яких СП запрограмована та детермінована уродженими інстинктами і фізіологією, не приймають рішень, в той час, як СП людини формується в результаті навчання, тому вона має можливість обирати визначені форми СП та повинна нести відповідальність за наслідки своїх дій та рішень. Багато підлітків знають, як тварини реалізовують репродуктивні інстинкти та помилково вважають чоловічу та жіночу сексуальність аналогічною); біологічні, статево-рольові розбіжності чоловіків та жінок, несхожість їх сексуальних реакцій, особистісних особливостей та суспільних очікувань щодо них; фактичні відомості про мастурбацію (для того, щоб розвіяти неправильні уявлення про їі роль на різних етапах життєвого циклу); сучасна інформація про гомосексуальність, права та особливі соціальні проблеми людей з гомосексуальною орієнтацією; позитивні та негативні наслідки статевого акту, а також вчинки, що можуть призвести до нього; місце сексуальних стосунків у сімейному та соціальному житті підлітка; обговорення життєвих та літературних прикладів із метою осмислення того факту, що почуття однієї людини можуть не відповідати почуттям іншої.

За цим повинна стояти визначена система цінностей (переконань), що характерна для менталітету країни. Такими базовими цінностями є: відповідальність, піклування про інших, особистість кожної людини, комунікація, інформація, самоконтроль. Отже, на вищезазначених засадах розроблена система психопрофілактики порушення сексуальної поведінки (ПСП) у підлітків. Розробляючи дану систему на основі отриманих результатів та аналізу світового досвіду, виокремили основні чинники ризику розвитку ПСП, а саме: неправильне загальне і статеве виховання; явна акцентуація характеру і наявність дисгармонійних рис особи; невміння вирішувати життєві проблеми і переводити конфлікт з одного виду в інший; дизонтогенез статевого розвитку; непідготовленість до гармонійних сексуальних стосунків, зокрема неадекватні мотиви вступу до статевих стосунків, відсутність достатніх знань про повноцінне сексуальне функціонування індивіда; дисгармонійні типи сексуальної мотивації та сексуальної культури, неадекватна статево-рольова і сексуально-еротична поведінка; порушення психосексуальної орієнтації.

Комплексність психопрофілактики - це правильне поєднання методів, форм і змісту заходів, що прово- дилися, комплекс яких повинен включати вплив сім'ї, школи, суспільних інститутів.

3 урахуванням викладеного нами, розроблено програму статевого виховання та сексуальної освіти для молоді в Україні, що складається з трьох частин: 1) анатомо-фізіологічної і гігієнічної; 2) соціальнопсихологічної (п'ять блоків); 3) юридичної. Також розроблено, апробовано та впроваджено психологічний тренінг, спрямований на формування відповідальної та безпечної сексуальної поведінки та психопрофілактику ПСП.

Висновки. Актуальність проблеми формування статевої культури школярів старшого підліткового віку зумовлена об'єктивними факторами (вплив суспільства, засобів масової інформації, друзів, сім'ї тощо) та суб'єктивними (ступінь самовизначеності особистості; рівень знань про наслідки невідповідального ставлення до статевого життя тощо).

Соціально-педагогічна діяльність з формування статевої культури старших підлітків має бути спрямована на попередження негативних наслідків ранніх статевих відносин, на активне формування особистості, її ціннісних орієнтацій, за якими вони будуватимуть своє майбутнє життя. Розроблена технологія включає три етапи: діагностувальний, формувальний, контрольний та реалізується через комплекс заходів, спрямованих на формування правильного уявлення про суть взаємовідносин статей і виховання у них, відповідно їх статі, норм поведінки.

Програми статевого виховання підлітків, в основу яких покладене виховання високої моралі та цноти, може містити такі концептуальні складові:

1) підлітки повинні знати, що це не тільки нормально, а й найбільш правильно сказати «ні» сексуальним стосункам до шлюбу;

2) підлітки повинні усвідомити, чому саме необхідно сказати «ні»;

3) підлітки повинні знати, як сказати «ні»;

4) підлітки повинні бачити переваги, які вони матимуть, відмовившись від сексу до шлюбу;

5) підліткам необхідні особистості, чий авторитет вони визнають, які можуть стати для них взірцями того, що цнота не тільки прийнятна, але й можлива та єдино правильна життєва позиція. 


\section{СПИСОК ЛІТЕРАТУРИ}

1. Гэри Чепмен. Пять языков любви / Гэри Чепмен. Львов : Издательский центр «Свит», 2003. - 108 с.

2. Дмитренко Т. О. Методологічні основи соціальної педагогіки / Т. О. Дмитренко, К. В. Яресько. - Харків : Крок, 2003. - 32 с.

3. Дру Кунс Созидая единство в браке (материалы для семейных пар) / Дру Кунс, Кит Кунс, Скотт Стемплом. - К. : Велес, 2006. - 66 с.

4. Запобігання і протидія насильству в сім'ї : методичні рекомендації для соціальних працівників. - К. : ДЦССМ, 2004. - 192 c.
5. Звоницький Е. В. Пастки для кожного. (Паління. Алкоголізм. Наркоманія. СНІД. Статеві відносини) / Е. В. Звоницький. - Б. : «Везелиця», 2002. - 36 с. : іл. (Учбово-методичне видання).

6. Ильин Е. П. Эмоции и чувства / Е. П. Ильин. - СПб. : Питер, 2002. - 752 с.: ил. - (Серия «Мастра психологии»).

7. Исаев Д. Н. Половое воспитание детей: медико-психологические аспекты / Д. Н. Исаев, В. Е. Каган. - 2-е изд., перераб. и доп. - Л. : Медицина, 1988. - 160 с.

8. Кон И. С. Психосексуальное развитие и половая социализация / И. С. Кон // Семейная психотерапия при нервных и психических заболеваниях. - Л. : Ленинградский психотерапевтический институт, 1978. - С.113-122.

Отримано 26.01.18 